\title{
The Relationship between Substance Use and Depressive Symptoms among Colombian Adolescents
}

\author{
K Romero-Acosta ${ }^{1}$, L Gómez-de-Regil ${ }^{2}$, G Lowe ${ }^{3}$, G Lipps ${ }^{4}$
}

\begin{abstract}
Objective: To explore the relationship between substance use and depressive symptomatology among adolescents in Colombia.

Methods: Adolescents aged 13-19 years from a rural city in Colombia completed the Spanish version of the Alcohol, Smoking and Substance Involvement Screening Test and the Kutcher Adolescent Depression Scale-6 (KADS-6).

Results: Regression analyses indicated that gender, having used cannabis, having used sedatives, and having a family member who used illegal drugs were predictive of higher symptom levels of depression according to KADS-6.

Conclusion: The results of this study suggested that substance use was associated with depressive symptoms in this sample of Colombian adolescents.
\end{abstract}

Keywords: Adolescent depression, substance use

\section{Relación entre el uso de sustancias y los síntomas depresivos entre adolescentes colombianos}

\author{
K Romero-Acosta ${ }^{1}$, L Gómez-de-Regil², G Lowe ${ }^{3}$, G Lipps ${ }^{4}$
}

\begin{abstract}
RESUMEN
Objetivo: Explorar la relación entre el uso de sustancias y la sintomatología depresiva entre adolescentes en Colombia.

Métodos: Los adolescentes de 13 a 19 años de una ciudad rural en Colombia completaron la versión en español de la Prueba de Detección de Alcohol, Tabaco y Sustancias (ASSIST, en inglés) y la Escala de Depresión pasa Adolescentes de Kutcher-6 (KADS-6, en inglés).

Resultados: Los análisis de regresión indicaron que tanto el género, como el haber consumido cannabis, usado sedantes, y tener un miembro de la familia que usó drogas ilegales, fueron predictores de niveles más altos de síntomas depresivos de acuerdo con la escala KADS-6.

Conclusión: Los resultados de este estudio sugirieron que el uso de sustancias estaba asociado con síntomas depresivos en esta muestra de adolescentes colombianos.
\end{abstract}

Palabras clave: Depresión adolescente, uso de sustancias

From: ${ }^{1}$ Corporación Universitaria del Caribe CECAR, Sincelejo, Sucre, Colombia, ${ }^{2}$ Hospital Regional de Alta Especialidad de la Península de Yucatán, Calle 7, No. 433 por 20 y 22, Fraccionamiento Altabrisa, Mérida, Yucatán, México, 97130, ${ }^{3}$ Department of Community Health and Psychiatry, Faculty of Medical Sciences, The University of the West Indies, Mona, Kingston, Jamaica, West Indies and ${ }^{4}$ Department of Sociololgy, Psychology and Social Work,
Faculty of Social Sciences, The University of the West Indies, Mona, Kingston, Jamaica, West Indies.

Correspondence: Dr L Gómez-de-Regil, Hospital Regional de Alta Especialidad de la Península de Yucatán, Calle 7, No. 433 por 20 y 22, Fraccionamiento Altabrisa, Mérida, Yucatán, México, 97130. Email: gomezderegil@gmail.com 


\section{INTRODUCTION}

Feeling sad and feeling anxious are normal emotions; however, the feeling of sadness is considered abnormal when, for at least two weeks, the individual falls into a depressed mood that leads to a loss of interest or pleasure in almost all activities of life (1). It is common that children and adolescents with depressive symptoms concurrently use illegal substances (2-5).

Adolescents with a predisposition to depressive symptoms who also have a family history of substance use may develop depressive symptoms at an expedited rate (2). Adolescents may also use illegal substances to help to reduce some dysphoric symptoms which are associated with depression (5).

In clinical samples, the co-occurrence of depression and substance use disorder is associated with greater functional impairment $(2,5)$. Individuals who do not meet the diagnostic criteria for clinical depression may exhibit sufficient symptoms that interfere with their daily life activities, misuse substances, and may have an elevated usage of mental health services $(3,4,6-9)$. Despite not reaching the threshold for clinical depression, studying this population of adolescents is important because this combination of factors may lead to chronic misuse of substances which may severely impact their lives.

Evidence suggests that internalizing symptoms may be related to the use of alcohol and illegal drugs $(3,6$, $8,10,11)$. Depressive symptoms seem to be positively associated with certain beliefs that promote substance use. It has been reported $(12,13)$ that adolescents with more symptoms of depression believe more strongly that substance use has social benefits, that friends and peers are having higher levels of substance misuse, and have more friends who misuse substances. These beliefs regarding substance use expose them to greater risk for using drugs and being depressed $(12,13)$.

In Colombia, a National Mental Health Study estimated that $5.2 \%$ of the participants abused substances, $2.8 \%$ were at risk of doing so, and the prevalence of affective disorders was estimated at 5.3\% (14). However, research exploring the link of substance use and depressive symptoms among Colombian adolescents is scarce. Even fewer studies have examined this association in rural adolescent populations.

Sincelejo, Sucre's capital city, is a Colombian urban municipality that has developed as a home to a large number of citizens displaced from their rural communities due to armed conflicts. It is characterized by high levels of vandalism, crime, illegal trafficking of drugs and high substance use (15). This set of unfavourable circumstances increases adolescents' vulnerability to the use of illegal substances, as well as high levels of depressive symptoms. The objective of this study was to explore the relationship between substance use and depressive symptoms in an adolescent community from Colombia.

\section{SUBJECTS AND METHODS}

\section{Subjects}

A total of 353 participants (184 males, 165 females and four participants who did not report their gender) were sampled from one public school and one private school located in Sincelejo, a district of Sucre, Colombia. The schools were chosen to represent the full spectrum of secondary schools in Sincelejo. The public school was selected as it primarily enrolled students from lowincome families. The private school was chosen as it enrolled students from middle- and upper-income families.

In both schools, the project was presented to the school principal and the academic staff for their approval. Parents provided their informed consent for their children to participate via consent forms sent home to students' parents. Students' confidentiality and freedom to decline participation in the study were guaranteed. Following approval from the schools and the parents, data were collected from adolescents on a single school day. From a total population of 370 registered students, 364 attended school on the day of data collection, and 353 provided signed parental consent forms, giving an overall response rate of $95.1 \%$. The study received ethical approval from the Research and Ethics Committee of the Corporación Universitaria del Caribe CECAR, Sincelejo, Sucre, Colombia.

\section{Measures}

Alcohol, Smoking and Substance Involvement Screening Test

The Spanish version of the Alcohol, Smoking and Substance Involvement Screening Test (ASSIST) was used to collect information on the participants' use of substances (16). This eight-section, self-report, screening test was developed by the World Health Organization to detect the use of nine classes of substances (tobacco, alcohol, cannabis, cocaine, amphetamines, inhalants, sedatives, hallucinogens and opioids) and any other illicit substances. It contains eight sections. The first section collects information on the use of nine substances that students may have ever used. Section two assesses 
students' frequency of use of the nine substances during the last three months. Sections three to seven collect information on problems associated with participants' use of the nine substances. The eighth section consists of a single question which asks if participants have ever used a drug by injection. Although the ASSIST was originally designed for and tested in adult populations ( $\geq$ 18 years old), it has been validly used with adolescents (17). Substance involvement scores were calculated for each of the nine substances to classify risk level as low, moderate or high.

\section{Kutcher Adolescent Depression Scale-6}

Depression was assessed with the six-item Kutcher Adolescent Depression Scale-6 (KADS-6), specifically designed to screen for depressive symptoms. The self-report items are rated on a four-point Likert scale, from 0 (hardly ever) to 3 (all of the time), with a possible total score ranging from 0 to 18 (18). Past research using Colombian adolescents found acceptable levels of internal consistency reliability (alpha $=0.66$ to 0.70 ). Used with a cut-off score of 6 , this scale has shown satisfactory sensitivity and specificity to screen for major depressive disorder in adolescents (19).

\section{Data analysis}

Firstly, descriptive analyses examining the frequency of lifetime substance use were performed. Following this, lifetime use of specific substances along with gender and with having a family member who used drugs was used in a multiple regression analysis to predict depressive symptoms.

\section{RESULTS}

\section{Depressive symptoms in the sample}

The sample $(\mathrm{n}=353)$ included $184(52.1 \%)$ males and 165 (46.7\%) females, with four (1.1\%) participants not reporting their gender. Ages ranged from 13 to 19 years $($ mean $=15.09$; standard deviation $(\mathrm{SD})=1.82)$. The mean KADS-6 score for the total sample was 3.89 (SD $=3.15)$, ranging from 0 to 17 . Females $($ mean $=4.81 ; \mathrm{SD}$ $=3.45)$ scored significantly higher than males (mean $=$ $3.09 ; \mathrm{SD}=2.75)\left(\mathrm{t}_{(313)}=5.2 ; p \leq 0.001\right)$.

\section{Lifetime use of substances}

Only 193 (54.7\%) participants had used at least one substance in their lifetime. No one had ever used drug by injection (section eight). The most commonly used substances were alcohol $(\mathrm{n}=115 ; 32.6 \%)$ and tobacco $(\mathrm{n}=$
$48 ; 13.6 \%)$. All other substances were less commonly used (Table 1).

\section{Predictors of depressive symptoms}

A multiple regression analysis was conducted using lifetime use of various substances, gender and family history of illegal substance use as predictors of depressive symptoms (Table 2). Results of this analysis indicated that being female, having used cannabis, having used sedatives and having a family member who used illegal drugs were all predictors of depressive symptoms $\left(\mathrm{R}^{2}=0.144\right)$.

Table 1: Frequency of lifetime use of substances

\begin{tabular}{lrr}
\hline & $\mathbf{n}$ & $\mathbf{\%}$ \\
\hline Have you ever used tobacco? & 48 & 13.6 \\
Have you ever used alcohol? & 115 & 32.6 \\
Have you ever used cannabis? & 8 & 2.3 \\
Have you ever used cocaine? & 2 & 0.6 \\
Have you ever used amphetamines? & 3 & 0.8 \\
Have you ever used inhalants? & 3 & 0.8 \\
Have you ever used sedatives or sleeping pills? & 10 & 2.8 \\
Have you ever used hallucinogens? & 1 & 0.3 \\
Have you ever used opioids? & 1 & 0.3 \\
Have you ever used other illegal drugs? & 2 & 0.6 \\
Does someone in the family use illegal drugs? & 54 & 15.3 \\
\hline
\end{tabular}

Table 2: Multiple regression analysis with gender, use of substances and use of illegal drugs by family members as predictors of Kutcher Adolescent Depression Scale-6 (KADS-6) depression scores

\begin{tabular}{|c|c|c|c|c|}
\hline & \multicolumn{2}{|c|}{$\begin{array}{l}\text { Unstandardized } \\
\text { coefficient }\end{array}$} & \multicolumn{2}{|c|}{$\begin{array}{c}\text { Standardized } \\
\text { coefficient }\end{array}$} \\
\hline & B & $\begin{array}{l}\text { STD } \\
\text { error }\end{array}$ & Beta & $\mathbf{t}$ \\
\hline Gender & 1.60 & 0.35 & 0.25 & $4.64 *$ \\
\hline Have you ever used tobacco? & 0.88 & 0.50 & 0.10 & 1.76 \\
\hline Have you ever used alcohol? & 0.59 & 0.39 & 0.08 & 1.52 \\
\hline Have you ever used cannabis? & 2.72 & 1.31 & 0.13 & $2.07 * *$ \\
\hline Have you ever used cocaine? & -6.75 & 4.56 & -0.16 & -1.48 \\
\hline Have you ever used amphetamines? & 2.86 & 3.10 & 0.07 & 0.92 \\
\hline Have you ever used inhalants? & -0.17 & 1.81 & -0.01 & -0.09 \\
\hline $\begin{array}{l}\text { Have you ever used sedatives or sleeping } \\
\text { pills? }\end{array}$ & 2.33 & 1.07 & 0.12 & $2.17 * *$ \\
\hline Have you ever used hallucinogens? & 5.48 & 6.25 & 0.09 & 0.88 \\
\hline Have you ever used opioids? & 0.41 & 3.12 & 0.01 & 0.13 \\
\hline Have you ever used other illegal drugs? & -1.59 & 3.12 & -0.04 & -0.51 \\
\hline $\begin{array}{l}\text { Does someone in the family use illegal } \\
\text { drugs? }\end{array}$ & 1.03 & 0.48 & 0.12 & $2.14 * *$ \\
\hline
\end{tabular}

$\mathrm{R}^{2}=0.144$

$* p<0.05$

$* * p<0.01$ 


\section{DISCUSSION}

Contrary to the national health data (14), our study showed less than half of the adolescent population had used a substance in their lifetime. Alcohol was the most frequently used substance, followed by tobacco. Teenagers who were female, used cannabis, used a sedative in their lifetime and who had a family member who used illegal substances reported higher symptom levels of depression according to KADS- 6 than their peers.

Consistent with findings by Lewinsohn et al, we also found that female adolescents were more likely to report higher symptom levels of depression according to KADS-6 (20). Lewinsohn et al also suggested that the gender difference in depression first emerged in middle adolescence (20).

The most frequently used substances (alcohol and tobacco) were not associated with higher symptom levels of depression according to KADS-6. In Colombia, alcohol and tobacco are legal substances. Thus, they are readily available to adolescents, despite legislation restricting sales to underage youth (under 18 years old). While affordability and availability of substances increase the likelihood of their consumption, teenagers from socio-economically deprived communities as well as those from dysfunctional family settings were found to be at an increased risk for drug use (21). This suggests that their use was determined by socialization and social factors rather than as an emotional coping strategy.

In contrast, the increased use of sedatives among adolescents who had higher symptom levels of depression according to KADS-6 may suggest that they were self-medicating as a result of insomnia, which is a feature of depression. Additionally, past research has shown that sedative use was more prevalent among female adolescents (22).

Further, some research has reported that cannabis in low doses also had a tranquilizing effect, suggesting that it may be used as an informal treatment for depression and anxiety $(23,24)$. However, other research has suggested that cannabis use during adolescence resulted in higher levels of depression and anxiety in adulthood. It has been suggested that cannabis use was not associated with depressive symptoms among teenagers who were currently depressed, unless they had a family member who used illegal substances (2).

Individuals admitted to substance abuse treatment facilities who had initiated substance use earlier in life ( $\leq 11$ years old) had higher proportions of co-occurring mental disorders, suggesting that early initiation to substance use may be an early indicator of mental disorders
(25-27). This relationship may be due to the modelling of parents' behaviour (2).

\section{CONCLUSION}

Based on the results of this study, there was an association between substance use and depressive symptoms in this sample of adolescents from Sincelejo, Colombia.

\section{AUTHOR CONTRIBUTIONS}

$\mathrm{K}$ Romero-Acosta conceived the paper, oversaw data collection, conducted preliminary data analyses, wrote the manuscript and approved the final version. L Gómezde-Regil participated in the study design, preliminary data analysis and interpretation, critically revised the manuscript and approved the final version. G Lipps and G Lowe participated in the study design, data analysis and interpretation, critically revised the manuscript and approved the final version.

\section{ACKNOWLEDGEMENTS}

This research project was supported by Corporación Universitaria del Caribe CECAR, Sincelejo, Sucre, Colombia (VICECT + I 0712017). The authors thank the study participants, project staff and research assistants.

\section{REFERENCES}

1. American Psychiatric Association. Diagnostic and statistical manual of mental disorders. Washington, DC: American Psychiatric Association; 2013.

2. Gorka SM, Shankman SA, Seeley JR, Lewinsohn PM. The moderating effect of parental illicit substance use disorders on the relation between adolescent depression and subsequent illicit substance use disorders. Drug and Alcohol Dependence 2013; 128: 1-7.

3. McKelvey KL, Ramo DE, Delucchi K, Rubinstein ML. Polydrug use among urban adolescent cigarette smokers. Addict Behav 2017; 66: 145-50.

4. Pettigrew S, Jongenelis M, Lawrence D, Rikkers W. Common and differential factors associated with abstinence and poly drug use among Australian adolescents. Int J Drug Policy 2017; 50: 41-7.

5. Rappeneau V, Berod A. Reconsidering depression as a risk factor for substance use disorder: insights from rodent models. Neuroscience and Biobehavioral Review 2017; 77: 303-16.

6. Carrellas NW, Biederman J, Uchida M. How prevalent and morbid are subthreshold manifestations of major depression in adolescents? A literature review. Journal of Affective Disorders 2017; 1: 166-73.

7. O’Neil KA, Conner BT, Kendell PC. Internalizing disorders and substance use disorders in youth: comorbidity, risk, temporal order, and implications for intervention. Clin Psychol Rev 2011; 31: 104-12.

8. Rhew IC, Fleming CB, Vander Stoep A, Nicodimos S, Zheng C, McCauley E. Examination of cumulative effects of early adolescent depression on cannabis and alcohol use disorder in late adolescence in a community-based cohort. Addiction 2017; 112: 1952-60.

9. Wesselhoeft R, Sørensen M, Heiervang E, Bilenberg N. Subtheshold depression in children and adolecents - a systematic review. Journal of Affective Disorders 2013; 151: 17-22.

10. Stapinski LA, Montgomery AA, Araya R. Anxiety, depression and risk of cannabis use: examining the internalising pathway to use among Chilean adolescents. Drug Alcohol Depend 2016; 166: 109-15. 
11. Welsh JW, Knight JR, Hou SS-Y, Malowney M, Schram P, Sheritt L et al. Association between substance use diagnoses and psychiatric disorders in an adolescent and young adult clinic-based population. J Adolesc Heal 2017; 60: 648-52.

12. Siennick SE, Widdowson AO, Woessner M, Feinberg ME. Internalizing symptoms, peer substance use, and substance use initiation. J Res Adolesc 2016; 26: 645-57.

13. Siennick SE, Widdowson AO, Woessner MK, Feinberg ME, Spoth RL. Risk factors for substance misuse and adolescents' symptoms of depression. J Adolesc Heal 2017; 60: 50-6.

14. Ministerio de Salud. Encuesta Nacional de Salud Mental 2015 [Internet]. 2018 [cited 2018 Feb 14]. Available from: www.minsalud.gov.co/ Documentos y Publicaciones/ESTUDIO NACIONAL DE SALUD MENTAL EN COLOMBIA.pdf.

15. Pérez D, Regino T, Gómez N, Castillo S, Romero-Acosta K. Presencia de sintomatología ansiosa en niños, niñas y adolescentes de 8 a 16 años de edad en Sincelejo (Sucre): Una comparación entre hijos de desplazados y de no desplazados. Revista Psicoespacios 2016; 10: 51-70.

16. Pan American Health Organization. The test for the detection of alcohol, tobacco and substances (ASSIST) - a manual for use in primary care. Washington, DC: World Health Organization; 2011.

17. Gryczynski J, Kelly SM, Mitchell SG, Kirk A, O’Grady KE, Schwartz RP. Validation and performance of the Alcohol, Smoking and Substance Involvement Screening Test (ASSIST) among adolescent primary care patients. Addiction 2015; 110: 240-7.

18. Kutcher S, Chehil S. Suicide risk management: a manual for health professionals. Wiley Online Library; 2007.

19. LeBlanc JC, Almudevar A, Brooks SJ, Kutcher S. Screening for adolescent depression: comparison of the Kutcher Adolescent Depression
Scale with the Beck Depression Inventory. Journal of Child and Adolescent Psychopharmacology 2002; 12: 113-26.

20. Lewinsohn PM, Gotlib IH, Lewinson M, Seeley JR. Gender differences in anxiety disorders and anxiety symptoms in adolescents. Journal of Abnormal Psychology 1998; 107: 109-17.

21. Anderson P. Global use of alcohol, drugs and tobacco. Drug Alcohol Rev 2006; 25: 489-502.

22. Jané-Llopis E, Matytsina I. Mental health and alcohol, drugs and tobacco: a review of the comorbidity between mental disorders and the use of alcohol, tobacco and illicit drugs. Drug Alcohol Rev 2006; 25: 515-36.

23. Das JK, Salam RA, Arshad A, Finkelstein Y, Bhutta ZA. Interventions for adolescent substance abuse: an overview of systematic reviews. J Adolesc Heal 2016; 59: 561-70.

24. Tambaro S, Bortolato M. Cannabinoid-related agents in the treatment of anxiety disorders: current knowledge and future perspectives. Recent patents on CNS drug discovery 2012; 7: 25-40.

25. Strashny A. Age of substance use initiation among treatment admissions aged 18 to 30. The CBHSQ Report. Rockville, Maryland, USA: Center for Behavioral Health Statistics and Quality, Substance Abuse and Mental Health Services Administration; July 17, 2014.

26. Hernandez L, Cancilliere MK, Graves H, Chun TH, Lewander W, Spirito A. Substance use and depressive symptoms among adolescents treated in a pediatric emergency department. J Child Adolesc Subst Abuse 2016; 25: 124-33.

27. Patton GC, Coffey C, Carlin JB, Degenhardt L, Lynskey M, Hall W. Cannabis use and mental health in young people: cohort study. BMJ 2002; 325: 1195-8. 